\title{
The role of sediments in the carbon and pollutant cycles in aquatic ecosystems
}

O papel dos sedimentos nos ciclos de carbono e poluentes em ecossistemas aquáticos

Simone Jaqueline Cardoso ${ }^{1,2 *}$ (D), Gabrielle Rabelo Quadra ${ }^{2}$ (D), Nathália da Silva Resende ${ }^{2}$ (D) and Fábio Roland ${ }^{2}$

${ }^{1}$ Programa de Pós-graduação em Ecologia, Departamento de Zoologia, Universidade Federal de Juiz de Fora - UFJF, Rua José Lourenço Kelmer, s/n, São Pedro, CEP 36036-900, Juiz de Fora, MG, Brasil

${ }^{2}$ Programa de Pós-graduação em Ecologia, Laboratório de Ecologia Aquática, Universidade Federal de Juiz de Fora - UFJF, Rua José Lourenço Kelmer, s/n, São Pedro, CEP 36036-900, Juiz de Fora, MG, Brasil

*e-mail: simone.jcardoso@gmail.com

Cite as: Cardoso, S.J. et al. The role of sediments in the carbon and pollutant cycles in aquatic ecosystems. Acta Limnologica Brasiliensia, 2019, vol. 31, e201

Abstract: Aim: Anthropogenic modifications in the landscape are accelerating biogeochemical cycles and causing unbalances in terrestrial and aquatic ecosystems with still unknow impacts on biotic and abiotic processes. Therefore, there has been increasing scientific interest in the links between human activities and ecosystems functions. Methods: Here we review the role of aquatic sediments in the carbon and pollutant cycle. Results: We briefly explore the historical context, origin, and composition of the sediments, as well as the factors that influence the processes of carbon and contaminants cycling and the role of sediments in the greenhouse gases emissions in aquatic ecosystems. Conclusions: Aquatic sediments can help to understand the terrestrial and aquatic ecosystem changes, once they are good sentinels, reflecting key biogeochemical processes over time.

Keywords: biogeochemical cycles; freshwater sediments; organic carbon mineralization; contaminants; anthropogenic activities.

Resumo: Objetivo: Modificaçóes antrópicas na paisagem estão acelerando os ciclos biogeoquímicos e promovendo desbalanços entre ecossistemas terrestres e aquáticos de maneira sem precedentes, com impactos ainda desconhecidos nos processos bióticos e abióticos. Desta forma, é crescente o interesse científico nas relaçóes entre atividades humanas e funções ecossistêmicas. Métodos: Neste trabalho, foi realizada uma revisão do papel dos sedimentos aquáticos nos ciclos do carbono e de poluentes. Resultados: Neste trabalho exploramos brevemente o contexto histórico, a origem e composição dos sedimentos, bem como os fatores que influenciam os processos de ciclagem do carbono e dos contaminantes, e o papel dos sedimentos nas emissóes de gases de efeito estufa em ecossistemas aquáticos. Conclusóes: Sedimentos aquáticos podem ajudar a compreender as mudanças nos ecossistemas terrestres e aquáticos, uma vez que são considerados bons sentinelas, capazes de refletir processos biogeoquímicos chave ao longo do tempo.

Palavras-chave: ciclos biogeoquímicos; sedimentos de água doce; mineralização do carbono orgânico; contaminantes; atividade antrópica. 


\section{Introduction}

Sediments are crucial for environmental research due to its relationship with eutrophication processes, chemical pollution, sedimentation and silting in aquatic ecosystems (Forsberg, 1989). These issues have become increasingly recurrent, especially in large urban centers and rural areas, and affect both natural (e.g., streams, rivers, ponds and lakes), and artificial systems (e.g., reservoirs for water supply and hydropower generation) (Apitz, 2012). These problems are challenging because they involve not only aquatic ecosystems, but also the processes that occur in the drainage basin scale. On the other hand, this situation shows the need for suitable solutions and alternatives for the management of aquatic systems, avoiding and minimizing the impacts at spatial and temporal scales. In order to better understand the processes taking place in the aquatic sediments, the following topics will be briefly discussed: the historical context, origin, and composition of the sediments, as well as the factors that influence the processes of organic matter in this compartment; the contributions of the sediments for $\mathrm{CH}_{4}$ and $\mathrm{CO}_{2}$ emissions to the atmosphere and their importance in natural and artificial environment transformations; and the importance of sediments in terms of aquatic ecosystems pollution. Lastly, some final considerations and perspectives for future studies will be presented.

\section{Aquatic Sediments: a Brief Historical Context}

Sediments of aquatic ecosystems have been studied for many years to characterize their properties for physical, chemical, biological, geological and cultural purposes (Apitz, 2012). Many analytical methods used for sediments have been adapted from soil and mineral exploration studies (Mudroch \& Macknight, 1994). In the beginning, the absence of adequate methods and equipment was a limiting factor for its systematic study, which only became effective after the invention of dredgers and profile collectors. Historically, sediment investigations for limnological purposes only began in $19^{\text {th }}$ century in order to better understand the matter and energy flows in aquatic ecosystems (Mudroch et al., 1996). The first study involving aquatic sediments date back to the 1862 . It was performed by Hampus von Post and was focused on describing the characteristics of Swedish lakes sediments (Von Post, 1862). Later on, in the $20^{\text {th }}$ century, Naumann described the metabolism in the sediments of temperate lakes
(Naumann, 1930), while Hummel performed the first investigations in the tropics, describing biogeochemical processes in the sediments of Indonesian lakes (Hummel, 1931). Currently, sediments are part of an important scenario of environmental issues related to greenhouse gas (GHG) emissions, the degradation of water resources, such as eutrophication, chemical pollution and silting processes, and their role in the carbon cycle at regional and global scales (Apitz, 2012).

\section{Origin and Composition of Aquatic Sediments}

Sediments are essentially unconsolidated materials, products of modification of rocks, soils, and organic matter that have undergone weathering, transportation, transformation and deposition near the Earth's surface or in water bodies (Figure 1). Depending on their origin, sediments may contain particles of different sizes, shapes, mineral and chemical compositions (Mudroch \& Macknight, 1994). When they are transported to aquatic ecosystems, by runoff, these particles settle in a differentiated way according to their nature. Generally, the coarsest material, such as sands ( $>62.5 \mu \mathrm{m}-<2 \mathrm{~mm})$ and pebbles (> $4 \mathrm{~mm}-<64 \mathrm{~mm}$ ), settle near the banks of lakes and in river gutters. Thinner particles, such as silts $(3.9-62.5 \mu \mathrm{m})$ and clay $(<3.9 \mu \mathrm{m})$, lodge themselves in deeper, lower-flow areas such as lake bottoms. Over time, this material tends to accumulate in the systems in proportions ranging from a few millimeters to many centimeters per year (Mudroch et al., 1996).

When sediments begin to integrate the aquatic ecosystems, they also interact with the biota and provide habitat and substrate for a wide variety of organisms. It is estimated that sediments of freshwater ecosystems (e.g., lakes, rivers, groundwater, and floodplains) shelter around 100,000 species of macroinvertebrates, 10,000 species of algae and more than 20,000 species of protozoa and bacteria (Palmer et al., 1997, 2000). These organisms, in turn, contribute to the sediment degradation, which, contain many organic and inorganic substances that will later be available to sediments and water column, subsidizing the trophic chains of aquatic ecosystems (Fenchel et al., 2012). Over time, sediments also receive contributions from allochthonous materials, mainly composed of terrestrial material originating from the drainage basin, which is transported by effluents and rainwater; and autochthonous species, composed of 


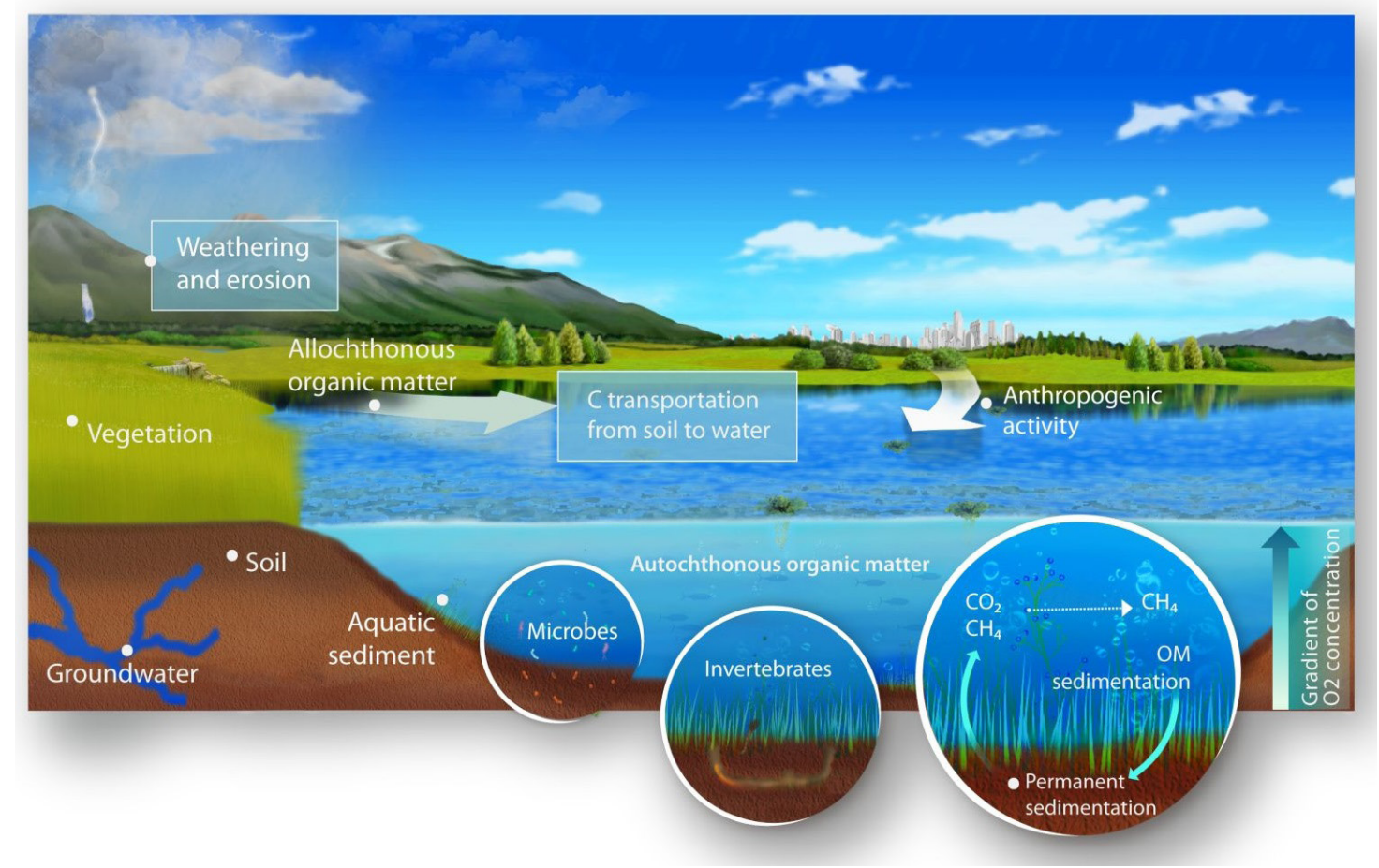

Figure 1. In the landscape, sediments are formed by unconsolidated materials, products of alteration of rocks, soils, and organic matter that have undergone weathering, transportation, transformation and deposition in terrestrial and aquatic ecosystems. Aquatic sediments can receive large amounts of allochthonous organic matter, mainly composed of terrestrial materials; and autochthonous organic matter, composed of algae, plants, and other animals originating from the aquatic environment itself. Once in the sediments, the organic matter of different origins and forms, can present three main destinations: 1 - be mineralized by microorganisms and invertebrates in the sediments and then returned to the water column as $\mathrm{CO}_{2}$ and $\mathrm{CH}_{4} ; 2$ - to undergo resuspension of the sediments and to be mineralized in the water column; or 3 - be permanently sedimented, functioning as a carbon stock in the sediments. All these factors also dependent on external factors such as morphological characteristics, hydrological conditions and water residence time in aquatic ecosystems, as well as anthropogenic activities.

algae, plants and other aquatic animals originating from the system itself (Figure 1).

As in the water column, the sediments also have a vertical zoning. In the vast majority of aquatic ecosystems, they are structurally formed by two main layers: i) superficial layer, also called a recent or biological layer; and ii) deep layer, also called permanent layer. The surface layer is in direct contact with the water column. It usually has only a few millimeters to centimeters, where oxygen and a greater amount of organic matter, nutrients, and benthic organisms are present, and therefore, it is considered the biologically active layer. The main processes of organic matter degradation mediated by the biota in the sediments are: resuspension, bioturbation and fractionation (benthic macroinvertebrates), photosynthesis (cyanobacteria, algae, and aquatic plants - when light is available), and decomposition (fungi and bacteria); besides the transformation by the biota, chemical and physical processes may also take place, such as ionic dissociation and diffusion (Forsberg, 1989). In the deep layer, sediments are more compact, where conditions of anoxia prevail. In this layer, the processes of ions solubilization are more frequent; there is a low content of organic matter and few organisms that are composed mainly of anaerobic bacteria and fungi (Fenchel et al., 2012).

\section{Organic Matter Mineralization in Aquatic Sediments}

Mineralization is the process of converting organic matter into inorganic matter, generating soluble compounds, gases, and energy (Megonigal et al., 2005). It is essential to sustain life, as it promotes the cycling of matter and energy in ecosystems. In aquatic sediments, mineralization is a complex process mediated by several factors such as: quantity and quality of organic matter reaching the sediments, availability of electron 
acceptors (e.g. oxygen, nitrate, iron, manganese and sulfate), structural characteristics of sediments (granulometry, water content, porosity, density), trophic conditions of the system, depth and mixing regime of the water column, temperature, $\mathrm{pH}$, concentrations of inorganic carbon and biota (Forsberg, 1989; Fenchel et al., 2012). The following is an overview of each of these processes.

\subsection{Quantity and the quality of the organic matter}

In aquatic ecosystems, sediment receive large amounts of autochthonous organic matter (OM) (from the Greek: auto \{self\} + khthon \{earth\}), composed of algae, plants, and other animals originating from the aquatic environment itself; and allochthonous (from the Greek: allos \{others\} + khton $\{$ earth\}), composed of terrestrial material. OM can also present two essential forms: particulate organic matter (POM) and dissolved organic matter (DOM). The organic matter present in aquatic ecosystems is mostly composed of proteins, lipids, carbohydrates, humic substances (e.g., humic and fulvic acids), plant tissues (rich in cellulose and hemicellulose) and animals, and other acids of different molecular weights (Benner, 2003). Generally, POM is composed of refractory materials, derived from the decomposition of aquatic macrophytes and lignocellulosic terrestrial residues; while DOM, besides being also refractory (Mayorga et al., 2005; Guillemette \& Del Giorgio, 2011), has more labile and soluble materials such as colloids and humic substances (Killops \& Killops, 2005). This OM can undergo transformations along the water column of the aquatic environments, and once in the sediments, this OM of different origins and forms, can present three main destinations: 1 - be mineralized by microorganisms in the sediments and then returned to the water column as $\mathrm{CO}_{2}$ and $\mathrm{CH}_{4} ; 2$ - undergo resuspension of the sediments and to be mineralized in the water column; or 3 - be permanently sedimented, functioning as a carbon stock in the sediments (Cardoso et al., 2013, Mendonça et al., 2016). The relative importance of each of these processes is system-specific and can influence its role as a sink or source of carbon to the atmosphere (Mendonça et al., 2012a).

The quantity and quality of $\mathrm{OM}$ that reaches the sediments results from a range of factors, such as the relative contribution of autochthonous sources (organic matter from primary production, usually more labile and easily degraded) and allochthons sources (terrestrial organic matter, more refractory and of slower degradation). It is also a result of the processes that occur in the water column, such as the partial mineralization of organic matter by aquatic microorganisms (Cole, 1999), and photodegradation (Bertilsson \& Tranvik 2000, von Wachenfeldt \& Tranvik, 2008; Farjalla et al., 2009). It is important to highlight that all these factors, and consequently the quantity and quality of OM, are closely related to the hydrology of the systems, a strong driving factor controlling the runoff of terrestrial material and transformation in the OM, as well as the transformations that occur in their drainage basin (Aitkenhead et al., 1999).

\subsection{Availability of electron acceptors}

After undergoing transformations in the water column and reaching the sediments, the $\mathrm{OM}$ is degraded by several redox reactions. These reactions release decreasing amounts of energy, ranging from more oxidative (greater release of energy) to less oxidative (less release of energy), and take into account the availability of the electron acceptors in the system (Fenchel et al., 2012). In the superficial layer, the oxygen reduction reactions (aerobic respiration) prevail, until the oxygen is exhausted. Subsequently, reactions of nitrate reduction (nitrification), manganese reduction, iron reduction, sulfate reduction and methanogenesis occur. After the reactions, the final products of anaerobic mineralization $\left(\mathrm{CH}_{4}, \mathrm{HS}, \mathrm{Fe}^{2+}, \mathrm{Mn}^{2+}\right)$ can dilute and diffuse in the water column or diffuse into the upper layer of the sediment where they can be reoxidized by different types of bacteria. In general, electron acceptors do not have homogeneous distribution in the systems and are also closely related to the origins and formation of aquatic sediments.

\subsection{Structural characteristics of the sediments - granulometry, water content, porosity and density}

In the sediments there are many grading scales of particles, or grains, which range from clay $(<3.9 \mu \mathrm{m})$ to gravel or boulders $(>256 \mathrm{~mm})$ (Mudroch \& Macknight, 1994). The grain size is an important ecological characteristic, once it is related to the substrate complexity and benthic community distribution (Strayer et al., 1997). Further, the quantification of the different particle sizes (i.e., granulometry) of sediment gives us information about its origin and biogeochemistry. More clayey sediments, for example, have a great capacity for ionic exchange and, therefore, play a fundamental role as chemical regulators 
in the sediments and in the water body, directly influencing the nutrient concentrations and organic matter mineralization processes (Mudroch \& Macknight, 1994).

Aquatic sediments have a great variety of size, geometric forms and chemical compositions (Mudroch \& Macknight, 1994). In these systems, sediments tend to form aggregates, which are a combination of minerals, organic matter, air, water and microorganisms. In sediment aggregates, there are also voids between particles, which are called pores. They can be occupied by both water and air. In sediment aggregates, the interstitial water that occupies the pores of the sediments acts as a solubilizing fluid for several ions and salts, which are essential for the occurrence of many chemical reactions and the existence and performance of microorganisms. Also, this pore water can have significant amounts of soluble $\mathrm{CO}_{2}$ and $\mathrm{CH}_{4}$ (Mendonça et al., 2016; Van Dijk et al., 2016), which can potentially contribute to carbon diffusion to the water column (Van Dijk et al., 2016; Aben et al., 2017; Call et al., 2018). In addition to water, these aggregates can also have spaces occupied by gases (air) such as $\mathrm{O}_{2}$, an important electron acceptor that is poorly soluble in water (Fenchel et al., 2012). The density of pores in the sediment particles is also important. Sediments particles with fewer pores (more compact), for example, tend to be denser and to sediment more rapidly in water bodies, while those with more pores tend to remain suspended in the water column for longer periods.

\subsection{Nutrient cycling and trophic conditions of the aquatic system}

Organic and inorganic nutrients, among them, mainly carbon, nitrogen, and phosphorus, are almost continuously transported to aquatic ecosystems and later to sediments through sedimentation (Forsberg, 1989). Upon reaching the sediments, these nutrients can be readily transformed by chemical, physical and biological processes and made available to sediments and water column, or they can be immobilized (stored) in the sediments, which occurs, especially when sedimentation rates are higher than transformation rates (Mudroch \& Macknight, 1994). This nutrient cycling is also dependent on external factors such as morphological characteristics, hydrological conditions and water residence time in aquatic ecosystems, as well as the relative contributions of different allochthonous and autochthonous sources of nutrients to sediments (Esteves, 2011).
The trophic conditions of aquatic ecosystems, in turn, are governed by the availability of these nutrients and influence directly the mineralization rates of organic matter in sediments (Fenchel et al., 2012). In sediments of oligotrophic ecosystems, for example, there is a lower primary production, which is mainly maintained by benthic algae. Due to these factors, more oxygen arrives and remains in the sediments, since it is not fully consumed in the water column, thus favoring aerobic mineralization processes (more energetic) in the sediments. However, because nutrients are also limiting for microorganisms, although there is more oxygen available to the sediments, mineralization rates may not be higher. On the other hand, in more eutrophic systems, where more nutrients are available, primary production is high, which is mainly maintained by macroalgae and phytoplankton. These organisms and others such as fish, invertebrates and zooplankton, in turn, use part of the nutrients and oxygen still in the water column limiting its reach in the sediments. With less oxygen reaching the sediments, there is a limitation of the more energetic mineralization processes (aerobic) and other organisms and electron acceptors, other than oxygen, begin to act in the process of mineralization of organic matter in the sediments, but with a lower energy balance. Because the anoxic condition prevails, production and emission of GHG gases, mainly $\mathrm{CH}_{4}$, become possible, once methane is only formed in the anoxic conditions. In turn, it has a global warming potential of almost 30 times higher than $\mathrm{CO}_{2}$.

\subsection{Depth and mixing regime of the water column}

The depth of aquatic ecosystems is also an essential factor for the organic matter mineralization in sediments. Deeper systems tend to have low mixing regimes (few water column mixing events throughout the year) and thermal and chemical stratification conditions during most of the year (Kalff, 2001). The thermal and chemical stratification of the water column may promote conditions of low temperatures and anoxia in hypolimnion and sediments. However, some studies have shown long lasting high temperatures in the sediments of some Amazonian lakes (Sanders et al., 2018). These conditions affect the organic matter mineralization rates, making them, in most cases, slower due to lower temperatures (Gudasz et al., 2010), and less energy efficiency due to anoxia conditions (Megonigal et al., 2005). Furthermore, a greater depth of the water column 
means more chance that the organic matter will be partially or totally degraded by the organisms in the water column, which means before reaching the sediments. Shallow systems, on the other hand, mix many times a year, mainly due to their morphometrics and climatic conditions such as wind and precipitation. In these systems, the sedimentation rate tends to be lower, and the oxygenation of the sediments is constant. These conditions allow the arrival of organic matter in greater quantities and qualities (less degraded) in the sediments. More oxygenated sediments, in turn, favor the occurrence of mineralization processes with higher energy efficiency (aerobic processes).

\subsection{Temperature}

The temperature modulates many chemical and biological processes in ecosystems, including organic matter degradation processes (Kirschbaum, 2006; Fenchel et al., 2012) and metabolism of aquatic organisms (Yvon-Durocher et al., 2010). Recent studies have shown that elevations in temperature increase the organic matter mineralization rates in aquatic sediments of different tropical (Cardoso et al., 2014; Marotta et al., 2014) and temperate regions (Gudasz et al., 2010). It is also important to note that other factors such as nutrients and electron acceptors availability in the sediments can act synergistically with the temperature in the control of organic matter mineralization rates (Cardoso et al., 2014). In general, given a global warming scenario, this effect can have significant consequences for the carbon cycle at different scales, as more carbon would be available to the atmosphere than would be permanently stored in the sediments of the ecosystems (Gudasz et al., 2010; Sobek et al., 2011).

\section{7. $p H$ and inorganic carbon concentrations}

$\mathrm{pH}$ is defined as the negative logarithm of the hydrogen ion concentration. Its scale varies between 0 and 14 and indicates acidity (between 0 and 7), neutral (7) or alkalinity (between 7 and 14) (Esteves, 2011). pH influences several chemical processes that occur in the water column and sediments, and its accurate measurement can provide valuable information about the biogeochemistry of the systems. $\mathrm{pH}$ variations, for example, may interfere in the concentrations of the different forms of inorganic carbon in the water column and sediments, which are $\mathrm{CO}_{2} \mathrm{H}_{2} \mathrm{CO}_{3}, \mathrm{HCO}_{3}^{-}$, and $\mathrm{CO}_{3}^{-2}$ (Esteves, 211). These different forms of inorganic carbon, in turn, are very important because they are buffer substances, responsible for stabilizing sudden $\mathrm{pH}$ changes in the system. Furthermore, they determine the amount of inorganic carbon available for photosynthesis, provide a great binding capacity of ion connection $\mathrm{HCO}_{3}^{-}$e $\mathrm{CO}_{3}^{-2}$, and remove inorganic carbon from the water column through the precipitation of $\mathrm{CaCO}_{3}$ aggregates (Kalff, 2001). In turn, it may influence the organic matter mineralization processes, sedimenting the final products of the redox reactions and avoiding their release into the water column and atmosphere (e.g., $\mathrm{CO}_{2}$; Cole, 2013).

\subsection{Biota}

Most organic matter mineralization occurs in the first $10 \mathrm{~cm}$ of sediment (Forsberg, 1989). This depth is composed of recent material and is, in most of the cases, the limit at which sediments can be altered by disturbances and mixing processes in the water column in shallow ecosystems, however variation may exist (Wetzel, 1983). This superficial layer is also considered as the most active layer due to the presence of benthic organisms. In relatively shallow systems with little suspended material in the water, the intense photosynthetic activity can also occur in the first $\mathrm{mm}$ to $\mathrm{cm}$ of sediment. This activity is mainly carried out by cyanobacteria, benthic algae and macrophytes (phytobenthos). Because of their photosynthetic activity, these organisms can promote diurnal changes in $\mathrm{O}_{2}$ e $\mathrm{CO}_{2}$ concentrations in the sediments and contribute to the partial diffusion of these gases to the water column (Fenchel et al., 2012).

Besides the primary producers found in this first centimiters of sediment, there are also some groups of protozoa, fungi, and viruses, which also help in the organic matter decomposition. Although their existence has already been mentioned in some studies, their ecological roles in the trophic sediment chains are still not well known (Fenchel et al., 2012). Benthic invertebrates, which use the sediment as a substrate and food, are on the surface and deeper layers of the sediments. They assist mainly in the mechanical degradation of organic matter, through the breaking of particles by mastication and digestion, as well as through the oxygenation of deeper layers of sediments through the tunnels they create by moving around. This as a great impact in the cycle of GHG gases, mainly methane, once this gas can be oxidized due to the oxygenation made by invertebrates when creating the tunnels. This process, in turn, may affect the concentrations of $\mathrm{CO}_{2}$ in the sediments, as $\mathrm{CO}_{2}$ is the product of the $\mathrm{CH} 4$ oxidation process. 
The most active and important community for the organic matter mineralization process along the entire sediment profile is the microbial community (Forsberg, 1989). It is a complex community with some microorganisms that exceeds many orders of magnitude $\left(>10^{9} \mathrm{~cm}^{-3}\right)$ the density found in the water column. It is composed of several groups with distinct functions and essentially heterotrophic activities (Fenchel et al., 2012). These organisms can perform the synthesis (chemosynthesis) and organic matter mineralization through respiration, denitrification, sulfate reduction, methanogenesis, and fermentation, which vary in their occurrence and intensity depending on the chemical and physical characteristics of the sediments. These processes, except for the sulfide and sulfate oxidation and nitrification processes, involve changes (consumption and production) in $\mathrm{CO}_{2}$ concentration which, in turn, is potentially diffused to the water column.

\section{Contribution of Sediment to $\mathrm{CH}_{4}$ and $\mathrm{CO}_{2}$ Emissions from Aquatic Ecosystems}

In the landscape, carbon is transported in two main directions: laterally through an aquatic continuum towards the oceans, and vertically through gas exchange with the atmosphere (photosynthesis and respiration, in the case of $\mathrm{CO}_{2}$ ), with permanent accumulation in soils and sediments (Regnier et al., 2013). Recent estimates calculate that freshwater ecosystems, on a global scale, receive about 5.1 Pg C annually from the drainage basin (Drake et al., 2018); of these, a portion returns to the atmosphere in the forms of $\mathrm{CH}_{4}$ and $\mathrm{CO}_{2}$ (ca. $3.88 \mathrm{Pg} \mathrm{C}$ ) (Sawakuchi et al., 2017), another portion is retained in the sediments (ca. 0.6 Pg) (Battin et al., 2009), photosynthesis (ca. 0.3) and $0.95 \mathrm{Pg} \mathrm{C}$ returns to the oceans (Cole et al., 2007; Regnier et al. 2013).

However, these estimates can be conservative, since they consider the sediments only as carbon reservoirs, neglecting their important role in the flows (essentially $\mathrm{CO}_{2}$ ) for the water column and atmosphere through the biogeochemical processes of organic matter mineralization (Battin et al., 2009). Mendonça and colleagues estimate a yearly OC burial of 0.15 (range, 0.06-0.25) Pg C in inland waters. However, the estimations are still very imprecise, mainly because the processes that lead to the organic matter mineralization in the water column and the sediments can vary spatially and temporally (Battin et al., 2009; Tranvik et al., 2009) and are also dependent on many local factors, as discussed in previous sections of this manuscript (e.g. quantity and quality of organic matter, electron acceptors availability, structural characteristics of sediments, trophic conditions of the system, etc.). Furthermore, the carbon fractions that are emitted to the atmosphere and permanently stored in the sediments are also interfered by the increasing human interventions in the landscape, such as changes in land use and occupation (e.g., deforestation, soil fertilization, urbanization, sewage treatment) and climate change (e.g., global warming and changes in precipitation regimes) (IPCC, 2007, 2013; Roland et al., 2012), intensified mainly from the $20^{\text {th }}$ century onwards (Sobek et al., 2003, Regnier et al., 2013).

Recent studies, for example, have pointed out that eutrophic environments tend to have high rates of mineralization, resulting in higher carbon emissions into the atmosphere and less accumulation of this element in the sediments (Bastviken et al., 2011; Pacheco et al., 2013). High carbon emissions have also been found in hydroelectric reservoirs, especially during the first years after flooding, when the mineralization of soil and flooded vegetation causes significant $\mathrm{CO}_{2}$ and $\mathrm{CH}_{4}$ emissions (Roland et al., 2010; Barros et al., 2011; Mendonça et al., 2012b). It is also estimated that elevations in global temperatures predicted for the next few years $\left(2^{\circ} \mathrm{C}\right.$ to $4^{\circ} \mathrm{C}$, IPCC, 2007,2013$)$ could cause a significant increase in the carbon mineralization rates in the sediments, resulting in higher carbon emissions to the atmosphere, and contributing to the worsening of the greenhouse effect (Gudasz et al., 2010; Regnier et al., 2013; Raymond et al., 2013). In general, knowledge about $\mathrm{CO}_{2}$ and $\mathrm{CH}_{4}$ emissions from sediments becomes more and more essential for an accurate carbon cycle balance in aquatic environments, and also to support strategic planning for the management and conservation of these environments (natural and artificial) at local, regional and global scales.

\section{Sediments as a Secondary Source of Pollutants}

Water availability is a big challenge for humankind, especially due to water pollution. Chemicals are known as important agents of global change (Bernhardt et al., 2017). Industrial development and urbanization release a variety of pollutants into the environment, with still unknown consequences to organisms (Förstner \& Wittmann, 1983; Filser, 2008; Cavalcanti et al., 2014). The urbanization process usually results in changes 
in land cover, soil erosion, and waste production, which leads to a chemical load on the surrounding water bodies, altering the ecosystem and leaving records of disturbances in the sediments (Förstner \& Wittmann, 1983). Several pollutants may be present in the sediments of aquatic ecosystems since many adsorb in this compartment, where they can stay for decades. Therefore, sediments act as a sink for pollutants (Salomons \& Förstner, 1984). However, adsorbed pollutants can be released into the water column and incorporated by biota. In this way, sediments may work as secondary source of pollutants, depending on environmental conditions (Salomons \& Förstner, 1984; Nizzetto et al., 2010). Thus, sediments are an essential tool to investigate water quality. It is possible to investigate past contamination, since sediments reflect the contamination accumulated over time, but also current contamination in surface layers, where the contaminants are more susceptible to be released to the water column again. Among the chemicals that occur in the aquatic environment, the most worrying are those that are susceptible to remobilization, bioaccumulation and biomagnification processes, such as heavy metals and organic pollutants (Salomon et al., 1995; Sobek et al., 2014).

Depending on the contaminant, the concentrations may be much higher in the sediments than in the water, which is constantly observed for heavy metals (Salomon et al., 1995). Heavy metals, such as cadmium and lead, are generally not removed from aquatic ecosystems by natural processes, suffering speciation and tending to accumulate in sediments (Förstner $\&$ Wittmann, 1983). Metals can be transferred through the food chain, eventually reaching humans, presenting a direct risk, being their environmental impact a major concern (Förstner \& Wittmann, 1983). The introduction of metals into freshwater ecosystems has several sources, including natural and human-made. Metals are abundant elements in the Earth's crust, and mineral weathering processes are responsible for the natural introduction of metals into aquatic environments (Salomon et al., 1995). On the other hand, anthropogenic sources include smelting and combustion of fuels, where metals undergo atmospheric deposition, garbage leaching, and industrial, domestic and agricultural effluent discharges (Förstner \& Wittmann, 1983; Salomons \& Förstner, 1984). Therefore, sediment contamination by metals is a diffuse problem, which needs to be studied in a transdisciplinary way.
Most metals are essential for life, but all can be toxic if they reach high levels in organisms. On the other hand, some metals do not have a known biological function and are mentioned as non-essential, such as cadmium and lead (Förstner \& Wittmann, 1983; Mason, 2013). Metals can cause lethal effects, but also sub lethal/chronic effects, such as reducing growth and fecundity, altering species composition, and decreasing population diversity and density (Moore \& Ramamoorthy, 2012). Humans influence the cycle of these contaminants by increasing their fluxes (Mason, 2013), but also through acidification and eutrophication, which affect the behavior of metals and change natural paths from rivers to oceans (Salomons \& Förstner, 1984). Also, anthropogenic activities release many other pollutants into the environment, and we know little about the simultaneous effects of mixtures on organisms. Thus, aquatic communities are continually exposed due to continuous discards.

The observed behavior of organic pollutants in aquatic ecosystems is not very different from metals, and it is a worldwide problem. Like metals, sediments also function as a reservoir for hydrophobic, recalcitrant, and dangerous pollutants. Many organic pollutants are considered persistent, since they have long half-lives in the environment, reaching years or even decades in the sediment. Depending on environmental processes, are also available for the biota by remobilization to the water column (Jones \& De Voogt, 1999; Nizzetto et al., 2010; Perelo, 2010; Sobek et al., 2014).

Another group of pollutants that deserves attention is the microplastics. Although the literature about microplastics in freshwater sediments is limited to few studies, mainly in the shorelines (Wagner et al., 2014; Klein et al., 2015), the properties and ecological effects of microplastics showed by marine literature may be applied to freshwater ecosystems. Microplastics are easily ingested by biota and may cause adverse effects (Eriksen et al., 2013; Goldstein et al., 2013; Remy et al., 2015). Moreover, some studies already showed that microplastics might adsorb organic pollutants, supporting the bioaccumulation and transportation of these compounds (Andrady, 2011; Ryan, 2014).

As sediments integrate the contamination over time, this aquatic compartment presents a range of possibilities for investigating pollution over time, from the beginning to the present day. Thus, it is possible to observe the trends of the concentrations over time, which allows inferring about the use and 
sources of the contaminants under investigation. This research field is called Paleolimnology (Last \& Smol, 2006). For example, Cooke \& Abbott (2008) investigate metal contamination in a lake in Peru. The authors found an increase in the metal concentration since 1925 but with the highest peak in the 1970s or 1980s according to each element studied. Then, the authors were able to infer about the industrialization period in that region (Cooke \& Abbott, 2008). The tool is also valuable for organic pollutants. For instance, Feingold \& Benoit (2018) studied lakes in the United States regarding contamination of DDT (dichloro-diphenyl-trichloroethane). DDT was widely used in World War II to prevent typhus in soldiers and later began to be used in agriculture. DDT was also used to control tropical diseases, such as malaria. However, due to its persistence, toxicology and bioaccumulation properties, DDT started to be banned worldwide (D'Amato et al., 2002). The authors found a peak of DDT concentration in the sediments during the large usage, however, due to banishment concentrations start to decrease over time (Feingold \& Benoit, 2018).

\section{Final Considerations}

Anthropogenic activies are posing pressure on aquatic ecosystems, and research on aquatic sediments deserve more attention, since they can contribute to the management and mitigation of impacts in different scales. The understanding of the processes of transport, deposition, and metabolism of carbon and contaminants in aquatic sediments is of fundamental importance, especially considering the significant role of these processes in the ecological responses of the aquatic ecosystems. Much has been learned about the process in aquatic sediments in the world. However, it is necessary to invest in the knowledge of such processes in natural and artificial environments under different conditions (e.g., temperature, trophic conditions), covering longer periods of sampling, so that a complete scenario of ecosystems and their main environmental drivers can be created. Further, the knowledge about $\mathrm{CO}_{2}$ and $\mathrm{CH}_{4}$ emissions from sediments should be improved to support an accurate carbon cycle balance in aquatic environments, and to improve the management and the conservation of these environments (natural and artificial) at different spatial resolutions. Besides that, studies in tropical regions should be encouraged, since data regarding these areas are still scarce. Therefore, sediment pollution should be a public health concern, since it can affect food from aquatic ecosystems, as well as drinking water. It is essential to invest in chemical removal and prevention techniques, such as reforestation of riparian zones with native species, investing in sewage treatment, restricting the use of fertilizers and pesticides in river basins, controlling the use of groundwater and implementation of environmental education and population participation to preserve water quality in ecosystems.

\section{Acknowledgements}

This work was supported by Coordination for the Improvement of Higher Education Personnel (CAPES) (fellowships to SJC and GRQ) and the National Council for Scientific and Technological Development (CNPq) (473141/2013-2 to FR).

\section{References}

ABEN, R.C.H., BARROS, N., VAN DONK, E., FRENKEN, T., HILT, S., KAZANJIAN, G., LAMERS, L.P.M., PEETERS, E.T.H.M., ROELOFS, J.G.M., DE SENERPONT DOMIS, L.N., STEPHAN, S., VELTHUIS, M., VAN DE WAAL, D.B., WIK, M., THORNTON, B.F., WILKINSON, J., DELSONTRO, T. and KOSTEN, $S$. Cross continental increase in methane ebullition under climate change. Nature Communications, 2017, 8(1), 1682. http://dx.doi.org/10.1038/s41467-01701535-y. PMid:29167452.

AITKENHEAD, J.A., HOPE, D. and BILLETT, M.F. The relationship between dissolved organic carbon in stream water and soil organic carbon pools at different spatial scales. Hydrological Processes, 1999, 13(8), 1289-1302. http://dx.doi.org/10.1002/ (SICI) 1099-1085(19990615)13:8<1289::AIDHYP766>3.0.CO;2-M.

ANDRADY, A.L. Microplastics in the marine environment. Marine Pollution Bulletin, 2011, 62(8), 1596-1605. http://dx.doi.org/10.1016/j. marpolbul.2011.05.030. PMid:21742351.

APITZ, S.E. Conceptualizing the role of sediment in sustaining ecosystem services: Sediment-ecosystem regional assessment (SEcoRA). The Science of the Total Environment, 2012, 415, 9-30. http:// dx.doi.org/10.1016/j.scitotenv.2011.05.060. PMid:21762956.

BARROS, N., COLE, J.J., TRANVIK, L.J., PRAIRIE, Y.T., BASTVIKEN, D., HUSZAR, V.L.M., DEL GIORGIO, P. and ROLAND, F. Carbon emission from hydroelectric reservoirs linked to reservoir age and latitude. Nature Geoscience, 2011, 4(9), 593-596. http://dx.doi.org/10.1038/ngeo1211. 
BASTVIKEN, D., TRANVIK, L.J., DOWNING, J.A., CRILL, P.M. and ENRICH-PRAST, A. Freshwater methane emissions offset the continental carbon sink. Science, 2011, 331(6013), 50-50. http://dx.doi. org/10.1126/science.1196808. PMid:21212349.

BATTIN, T.J., LUYSSAERT, S., KAPLAN, L.A., AUFDENKAMPE, A.K., RICHTER, A. and TRANVIK, L.J. The boundless carbon cycle. Nature Geoscience, 2009, 2(9), 598-600. http://dx.doi. org/10.1038/ngeo618.

BENNER, R. Molecular indicators of the bioavailability of dissolved organic matter. In: Findlay, S.E.G. and Sinsabaugh, R.L., ed. Aquatic Ecosystems interactivity of dissolved organic matter. San Diego, California: Academic Press, 2003, 121-135. http://dx.doi. org/10.1016/B978-012256371-3/50006-8.

BERNHARDT, E.S., ROSI, E.J. and GESSNER, M.O. Synthetic chemicals as agents of global change. Frontiers in Ecology and the Environment, 2017, 15(2), 84-90. http://dx.doi.org/10.1002/fee.1450.

BERTILSSON, S. and TRANVIK, L. Photochemical transformation of dissolved organic matter in lakes. Limnology and Oceanography, 2000, 45(4), 753-762. http://dx.doi.org/10.4319/lo.2000.45.4.0753.

CALL, M., SANDERS, C.J., ENRICH-PRAST, A., SANDERS, L., MAROTTA, H., SANTOS, I.R. and MAHER, D.T. Radon-traced pore-water as a potential source of $\mathrm{CO} 2$ and $\mathrm{CH} 4$ to receding black and clear water environments in the Amazon Basin. Limnology and Oceanography Letters, 2018, 5(5), 1-9. http://dx.doi.org/10.1002/lol2.10089.

CARDOSO, S.J., VIDAL, L.O., MENDONÇA, R.F., TRANVIK, L.J., SOBEK, S. and FÁBIO, R. SPATIAL variation of sediment mineralization supports differential $\mathrm{CO} 2$ emissions from a tropical hydroelectric reservoir. Frontiers in Microbiology, 2013, 4, 1-8. http://dx.doi.org/10.3389/ fmicb.2013.00101. PMid:23641239.

CARDOSO, S.J., ENRICH-PRAST, A., PACE, M.L. and ROLAND, F. Do models of organic carbon mineralization extrapolate to warmer tropical sediments? Limnology and Oceanography, 2014, 59(1), 48-54. http://dx.doi.org/10.4319/ lo.2014.59.1.0048.

CAVALCANTI, P.P., RODRIGUES, L.C.A., BEIJO, L.A., BARBOSA, S., XAVIER, T.T. and MAGALHAES, F. Contamination from an affluent of Furnas reservoir by trace metals. Brazilian Journal of Biology = Revista Brasileira de Biologia, 2014, 74(4), 877-885. http://dx.doi.org/10.1590/15196984.07013. PMid:25627598.

COLE, J.J. Aquatic microbiology for ecosystem scientists: new and recycled paradigms in ecological microbiology. Ecosystems (New York, N.Y.), 1999, 2(3), 215-225. http://dx.doi.org/10.1007/ s100219900069.
COLE, J.J., PRAIRIE, Y.T., CARACO, N.F., MCDOWELL, W.H., TRANVIK, L.J., STRIEGL, R.G., DUARTE, C.M., KORTELAINEN, P., DOWNING, J.A., MIDDELBURG, J.J. and MELACK, J. Plumbing the global carbon cycle: Integrating inland waters into the terrestrial carbon budget. Ecosystems (New York, N.Y.), 2007, 10(1), 171-184. http://dx.doi.org/10.1007/s10021-0069013-8.

COLE, J.J. The carbon cycle. With a brief introduction to global biogeochemistry In: K.C. Weathers, D.L. Strayer, G.F. Likens, eds. Fundamentals of ecosystems science. Waltham: Elsevier, 2013, pp. 109-132. http:// dx.doi.org/10.1016/B978-0-08-091680-4.00006-8.

COOKE, C.A. and ABBOTT, M.B. A paleolimnological perspective on industrial-era metal pollution in the central Andes, Peru. The Science of the Total Environment, 2008, 393(2-3), 262-272. http://dx.doi.org/10.1016/j.scitotenv.2007.12.034. PMid:18261764.

D'AMATO, C., TORRES, J.P.M. and MALM, O. DDT (dicloro difenil tricloroetano): toxicidade e contaminação ambiental-uma revisão. Quimica Nova, 2002(6a), 25, 995-1002. http://dx.doi.org/10.1590/ S0100-40422002000600017.

DRAKE, T.W., RAYMOND, P.A. and SPENCER, R.G.M. Terrestrial carbon inputs to inland waters: a current synthesis of estimates and uncertainty. Limnology and Oceanography Letters, 2018, 3(3), 132-142. http://dx.doi.org/10.1002/lol2.10055.

ERIKSEN, M., MAXIMENKO, N., THIEL, M., CUMMINS, A., LATTIN, G., WILSON, S., HAFNER, J., ZELLERS, A. and RIFMAN, S. Plastic pollution in the South Pacific subtropical gyre. Marine Pollution Bulletin, 2013, 68(1-2), 71-76. http://dx.doi.org/10.1016/j.marpolbul.2012.12.021. PMid:23324543.

ESTEVES, F.A. Fundamentos de limnologia. Rio de Janeiro: Interciência, 2011.

FARJALLA, V.F., AMADO, A.M., SUHETT, A.L. and MEIRELLES-PEREIRA, F. DOC removal paradigms in highly humic aquatic ecosystems. Environmental Science and Pollution Research International, 2009, 16(5), 531-538. http://dx.doi. org/10.1007/s11356-009-0165-x. PMid:19462194.

FEINGOLD, B.J. and BENOIT, G. A novel method to infer historical DDT use on Cape Cod, Massachusetts (USA), based on $\mathrm{DDDT}$ degradation and $210 \mathrm{~Pb}$ dating in lake sediment cores. Journal of Paleolimnology, 2018, 60(4), 461-472. http://dx.doi. org/10.1007/s10933-018-0034-z.

FENCHEL, T., KING, G. and BLACKBURN, T. Bacterial biogeochemistry: the ecophysiology of mineral cycling. London: Academic Press, 2012.

FILSER, J. Ecotoxicology and ecosystems: Relevance, restrictions, research needs. Basic and Applied Ecology, 
2008, 9(4), 333-336. http://dx.doi.org/10.1016/j. baae.2007.08.009.

FORSBERG, C. Importance of sediments in understanding nutrient cycling in lakes. Hydrobiologia, 1989, 176/177(1), 263-277. http:// dx.doi.org/10.1007/BF00026561.

FÖRSTNER, U. and WITTMANN, G.T.W. Metal pollution in the aquatic environment. New York: Springer-Verlag, 1983.

GOLDSTEIN, M.C., TITMUS, A.J. and FORD, M. Scales of spatial heterogeneity of plastic marine debris in the northeast Pacific Ocean. PLoS One, 2013, 8(11), e80020. http://dx.doi.org/10.1371/journal. pone.0080020. PMid:24278233.

GUDASZ, C., BASTVIKEN, D., STEGER, K., PREMKE, K., SOBEK, S. and TRANVIK, L.J. Temperature-controlled organic carbon mineralization in lake sediments. Nature, 2010, 466(7305), 478-U473. http://dx.doi.org/10.1038/ nature09186. PMid:20651689.

GUillemeTte, F. and DEL GiORGIO, P.A. Reconstructing the various facets of dissolved organic carbon bioavailability in freshwater ecosystems. Limnology and Oceanography, 2011, 56(2), 734-748. http://dx.doi.org/10.4319/lo.2011.56.2.0734.

HUMMEL, K. Sedimente indonesischer subwasscrseen. Archiv für Hydrobiologie, 1931, 8, 615-676. Supplement.

INTERGOVERNMENTAL PANEL ON CLIMATE CHANGE - IPCC. Fourth assessment report. Genebra: IPCC, 2007.

INTERGOVERNMENTAL PANEL ON CLIMATE CHANGE - IPCC. The physical science basis. IPCC working group I contribution to the fifth assessment report (AR5). Genebra: IPCC, 2013.

JONES, K.C. and DE VOOGT, P. Persistent organic pollutants (POPs): state of the science. Environmental Pollution, 1999, 100(1-3), 209-221. http:// dx.doi.org/10.1016/S0269-7491(99)00098-6. PMid:15093119.

KALFF, J. Limnology. New York: Prentice-Hall, 2001.

KILLOPS, S.D. and KILLOPS, V.J. Introduction to organic geochemistry. New York: Blackwell Publishing, 2005.

KIRSCHBAUM, M.U.F. The temperature dependence of organic-matter decomposition - still a topic of debate. Soil Biology \& Biochemistry, 2006, 38(9), 2510-2518. http://dx.doi.org/10.1016/j. soilbio.2006.01.030.

KLEIN, S., WORCH, E. and KNEPPER, T.P. Occurrence and spatial distribution of microplastics in river shore sediments of the Rhine-Main area in Germany. Environmental Science \& Technology, 2015, 49(10), 6070-6076. http://dx.doi.org/10.1021/acs. est.5b00492. PMid:25901760.
LAST, W.M. and SMOL, J.P. Tracking environmental change using lake sediments: physical and geochemical methods. USA: Springer Science \& Business Media, 2006.

MARotTa, H., Pinho, L., GUdASZ, C., BASTVIKEN, D., TRANVIK, L.J. and ENRICHPRAST, A. Greenhouse gas production in lowlatitude lake sediments responds strongly to warming. Nature Climate Change, 2014, 4(6), 467-470. http:// dx.doi.org/10.1038/nclimate2222.

MASON, R.P. Trace metals in aquatic systems. Hoboken: John Wiley \& Sons, 2013. http://dx.doi. org/10.1002/9781118274576.

MAYORGA, E., AUFDENKAMPE, A.K., MASIELLO, C.A., KRUSCHE, A.V., HEDGES, J.I., QUAY, P.D., RICHEY, J.E. and BROWN, T.A. Young organic matter as a source of carbon dioxide outgassing from Amazonian rivers. Nature, 2005, 436(7050), 538-541. http://dx.doi.org/10.1038/ nature03880. PMid:16049484.

MEGONIGAL, J.P., HINE, M.E. and VISSCHER, P.T. Anaerobic metabolism: linkages to trace gases and aerobic processes. In: W. SCHLESINGER, ed. Biogeochemistry. USA: Elsevier, 2005, pp. 317-392.

MENDONÇA, R., KOSTEN, S., SOBEK, S., BARROS, N., COLE, J.J., TRANVIK, L.J. and ROLAND, F. Hydroelectric carbon sequestration. Nature Geoscience, 2012a, 5(12), 838-840. http:// dx.doi.org/10.1038/ngeo1653.

MENDONÇA, R., BARROS, N., VIDAL, L.O., PACHECO, F., KOSTEN, S. and ROLAND, F. Greenhouse gas emissions from hydroelectric reservoirs: what knowledge do we have and what is lacking? In: G. LIU, ed. Greenhouse gases - emission, measurement and management. London: InTech, 2012b. http://dx.doi.org/10.5772/32752.

MENDONÇA, R., KOSTEN, S., SOBEK, S., CARDOSO, S.J., FIGUEIREDO-BARROS, M.P., ESTRADA, C.H.D. and ROLAND, F. Organic carbon burial efficiency in a subtropical hydroelectric reservoir. Biogeosciences, 2016, 13(11), 3331-3342. http://dx.doi.org/10.5194/bg-13-3331-2016.

MOORE, J.W. and RAMAMOORTHY, S. Heavy metals in natural waters: applied monitoring and impact assessment. Springer Science \& Business Media, 2012.

MUDROCH, A. and MACKNIGHT, S.D. Handbook of techniques for aquatic sediments sampling. 2nd ed. Boca Raton: CRC Press Inc., 1994. http://dx.doi. org/10.1201/9781466571761.

MUDROCH, A., AZCUE, J.M. and MUDROCK, P. Manual of physico-chemical analysis of aquatic sediments. Boca Raton: CRC Press Inc., 1996.

NAUMANN, E. Einführung im die Bodenkunde der Seen. Stuttgart: E. Schweizerbart'sche Verlagsbuchandlung, 1930 
NIZZETTO, L., MACLEOD, M., BORGÅ, K., CABRERIZO, A., DACHS, J., DI GUARDO, A., GHIRARDELLO, D., HANSEN, K.M., JARVIS, A., LINDROTH, A., LUDWIG, B., MONTEITH, D., PERLINGER, J.A., SCHERINGER, M., SCHWENDENMANN, L., SEMPLE, K.T., WICK, L.Y., ZHANG, G. and JONES, K.C. Past, present, and future controls on levels of persistent organic pollutants in the global environment. Environmental Science \& Technology, 2010, 44(17), 6526-6531. http://dx.doi.org/10.1021/es100178f. PMid:20604560.

PACHECO, F.S., ROLAND, F. and DOWNING, J. Eutrophication reverses whole-lake carbon budgets. Inland Waters, 2013, 4(1), 41-48. http://dx.doi. org/10.5268/IW-4.1.614.

PALMER, M.A., COVICH, A.P., FINLAY, B.J., GIBERT, J., HYDE, K.D., JOHNSON, R.K., KAIRESALO, T., LAKE, P.S., LOVELL, C.R., NAIMAN, R.J., RICCI, C., SABATER, F. and STRAYER, D. Biodiversity and ecosystem processes in freshwater sediments. Ambio, 1997, 26, 571-577.

PALMER, M.A., COVICH, A.P., LAKE, S., BIRO, P., BROOKS, J.J., COLE, J., DAHM, C., GIBERT, J., GOEDKOOP, W., MARTENS, K., VERHOEVEN, J. and VAN DE BUND, W.J. Linkages between aquatic sediment biota and life above sediments as potential drivers of biodiversity and ecological processes. Bioscience, 2000, 50(12), 1062-1075. http://dx.doi.org/10.1641/00063568(2000)050[1062:LBASBA]2.0.CO;2.

PERELO, L.W. In situ and bioremediation of organic pollutants in aquatic sediments. Journal of Hazardous Materials, 2010, 177(1-3), 81-89. http://dx.doi.org/10.1016/j.jhazmat.2009.12.090. PMid:20138425.

RAYMOND, P.A., HARTMANN, J., LAUERWALD, R., SOBEK, S., MCDONALD, C., HOOVER, M., BUTMAN, D., STRIEGL, R., MAYORGA, E., HUMBORG, C., KORTELAINEN, P., DÜRR, H., MEYBECK, M., CIAIS, P. and GUTH, P. Global carbon dioxide emissions from inland waters. Nature, 2013, 503(7476), 355-359. http://dx.doi. org/10.1038/nature12760. PMid:24256802.

REGNIER, P., FRIEDLINGSTEIN, P., CIAIS, P., MACKENZIE, F.T., GRUBER, N., JANSSENS, I.A., LARUELLE, G.G., LAUERWALD, R., LUYSSAERT, S., ANDERSSON, A.J., ARNDT, S., ARNosti, C., BORGES, A.V., DALE, A.W., GALLEGO-SALA, A., GODDÉRIS, Y., GOOSSENS, N., HARTMANN, J., HEINZE, C., ILYINA, T., JOOS, F., LAROWE, D.E., LEIFELD, J., MEYSMAN, F.J.R., MUNHOVEN, G., RAYMOND, P.A., SPAHNI, R., SUNTHARALINGAM, P. and THULLNER, $M$. Anthropogenic perturbation of the carbon fluxes from land to ocean. Nature Geoscience, 2013, 6(8), 597-607. http://dx.doi.org/10.1038/ngeo1830.

REMY, F., COLLARD, F., GILBERT, B., COMPÈRE, P., EPPE, G. and LEPOINT, G. When microplastic is not plastic: the ingestion of artificial cellulose fibers by macrofauna living in seagrass macrophytodetritus. Environmental Science \& Technology, 2015, 49(18), 11158-11166. http://dx.doi.org/10.1021/acs. est.5b02005. PMid:26301775.

ROLAND, F., HUSZAR, V.L.M., FARJALLA, V.F., ENRICH-PRAST, A., AMADO, A.M. and OMETTO, J.P.H.B. Climate change in Brazil: perspectives on the biogeochemistry of inland water. Brazilian Journal of Biology $=$ Revista Brasileira de Biologia, 2012, 72(3), 709-722. Supplement. http:// dx.doi.org/10.1590/S1519-69842012000400009. PMid:23011300.

ROLAND, F., VIDAL, L.O., PACHECO, F.S., BARROS, N.O., ASSIREU, A., OMETTO, J.P.H.B., CIMBLERIS, A.C.P. and COLE, J.J. Variability of carbon dioxide flux from tropical (Cerrado) hydroelectric reservoirs. Aquatic Sciences, 2010, 72(3), 283-293. http://dx.doi.org/10.1007/ s00027-010-0140-0.

RYAN, P.G. Litter survey detects the South Atlantic 'garbage patch'. Marine Pollution Bulletin, 2014, 79(1-2), 220-224. http://dx.doi.org/10.1016/j. marpolbul.2013.12.010. PMid:24360332.

SALOMON, W., FÖRSTNER, U. and MADER, P. Heavy metals: problems and solutions. USA: Springer Science \& Business Media, 1995.

SALOMONS, W. and FÖRSTNER, U. Metals in the hydrocycle. USA: Springer Science \& Business Media, 1984. http://dx.doi.org/10.1007/978-3642-69325-0.

SANDERS, L.M., TAFFS, K., STOKES, D., SANDERS, C.J., ENRICH-PRAST, A., AMORANOGUEIRA, L. and MAROTTA, H. Historic carbon burial spike in an Amazon floodplain lake linked to riparian deforestation near Santarém, Brazil. Biogeosciences, 2018, 15(2), 447-455. http://dx.doi. org/10.5194/bg-15-447-2018.

SAWAKUCHI, H.O., NEU, V., WARD, N.D., BARROS, M.L.C., VALERIO, A.M., GAGNEMAYNARD, W., CUNHA, A.C., LESS, D.F.S., DINIZ, J.E.M., BRITO, D.C., KRUSCHE, A.V. and RICHEY, J.E. Carbon dioxide emissions along the lower Amazon River. Frontiers in Marine Science, 2017, 4, 4-76. http://dx.doi.org/10.3389/ fmars.2017.00076.

SOBEK, A., WIBERG, K., SUNDQVIST, K.L., HAGLUND, P., JONSSON, P. and CORNELISSEN, G. Coastal sediments in the Gulf of Bothnia as a source of dissolved PCDD/ Fs and PCBs to water and fish. The Science of the Total Environment, 2014, 487, 463-470. 
http://dx.doi.org/10.1016/j.scitotenv.2014.04.041. PMid:24802269.

SOBEK, S., ALGESTEN, G., BERGSTRÖM, A.K., JANSSON, M. and TRANVIK, L.J. The catchment and climate regulation of $\mathrm{pCO} 2$ in boreal lakes. Global Change Biology, 2003, 9(4), 630-641. http:// dx.doi.org/10.1046/j.1365-2486.2003.00619.x.

SOBEK, S., ZURBRUGG, R. and OSTROVSKY, I. The burial efficiency of organic carbon in the sediments of Lake Kinneret. Aquatic Sciences, 2011, 73(3), 355-364. http://dx.doi.org/10.1007/s00027011-0183-x.

STRAYER, D.L., MAY, S.E., NIELSEN, P., WOLLHEIM, W. and HAUSAM, S. Oxygen, organic matter, and sediment granulometry as controls on hyporheic animal communities. Archiv für Hydrobiologie, 1997, 140(1), 131-144. http://dx.doi. org/10.1127/archiv-hydrobiol/140/1997/131.

TRANVIK, L.J., DOWNING, J.A., COTNER, J.B., LOISELLE, S.A., STRIEGL, R.G., BALLATORE, T.J., DILlON, P., FINLAY, K., FORTINO, K., KNOLL, L.B., KORTELAINEN, P.L., KUTSER, T., LARSEN, S., LAURION, I., LEECH, D.M., MCCALLISTER, S.L., MCKNIGHT, D.M., MELACK, J.M., OVERHOLT, E., PORTER, J.A., PRAIRIE, Y., RENWICK, W.H., ROLAND, F., SHERMAN, B.S., SCHINDLER, D.W., SOBEK, S., TREMBLAY, A., VANNI, M.J., VERSCHOOR, A.M., VON WACHENFELDT, E. and WEYHENMEYER, G.A. Lakes and reservoirs as regulators of carbon cycling and climate. Limnology and Oceanography, 2009, $54(6$ Part 2), 2298-2314. http://dx.doi.org/10.4319/ lo.2009.54.6_part_2.2298.

VAN DIJK, G., NIJP, J.J., METSELAAR, K., LAMERS, L.P.M. and SMOLDERS, A.J.P. Salinityinduced increase of the hydraulic conductivity in the hyporheic zone of coastal wetlands. Hydrological Processes, 2016, 31(4), 880-890. http://dx.doi. org/10.1002/hyp.11068.

VON POST, H. Studies öfver nutidens koprogena jordbildningar. Gyttja, dy och mylla. Kungl. Svenska Vetenskapsakademiens Handlingar, 1862, 4(1), 1-59.

VON WACHENFELDT, E. and TRANVIK, L.J. Sedimentation in boreal lakes: the role of flocculation of allochthonous dissolved organic matter in the water column. Ecosystems (New York, N.Y.), 2008, 11(5), 803-814. http://dx.doi.org/10.1007/s10021008-9162-z.

WAGNER, M., SCHERER, C., ALVAREZ-MUÑOZ, D., BRENNHOLT, N., BOURRAIN, X., BUCHINGER, S., FRIES, E., GROSBOIS, C., KLASMEIER, J., MARTI, T., RODRIGUEZMOZAZ, S., URBATZKA, R., VETHAAK, D., WINTHER-NIELSEN, M. and REIFFERSCHEID, G. Microplastics in freshwater ecosystems: what we know and what we need to know. Environmental Sciences Europe, 2014, 26(1), 12. http://dx.doi.org/10.1186/s12302-014-0012-7. PMid:28936382.

WETZEL, R.G. Limnology. 2nd ed. Philadelphia: Saunders Company, 1983.

YVON-DUROCHER, G., JONES, J.I., TRIMMER, M., WOODWARD, G. and MONTOYA, J.M. Warming alters the metabolic balance of ecosystems. Philosophical Transactions of the Royal Society of London. Series B, Biological Sciences, 2010, 365(1549), 2117-2126. http://dx.doi.org/10.1098/ rstb.2010.0038. PMid:20513719.

Received: 11 October 2018 Accepted: 30 July 2019 